See Article page 34 .

\section{Commentary: Late calcific fractures of expanded polytetrafluoroethylene neochordae: Blending techniques and a greater number of neochordae for durable mitral repair}

\author{
Amit Pawale, MD, and Patrick M. McCarthy, MD
}

There are multiple surgical techniques to treat leaflet prolapse in degenerative mitral valve repair. Classic Carpentier leaflet resection and sliding leaflet plasty, ${ }^{1}$ limited leaflet resections, folding leaflet plasty, chordal transfers and shortenings, papillary muscle repositioning, and the addition of expanded polytetrafluoroethylene (ePTFE) (Gore-Tex; W.L. Gore \& Associates, Inc, Newark, Del) chordae.

PTFE is a linear nonabsorbent polymer that is electronegative with a surface charge that mimics normal endothelium and less thrombogenicity. PPTFE has a porous microstructure with high breaking strength. Since testing of ePTFE in sheep ${ }^{2}$ and its introduction to the field of mitral valve surgery, ${ }^{3,4}$ this material has been used widely. ePFTE has been used as a single or multiple chordae, premeasured loops, loop-in-loop. It has been used in combination with leaflet resection or as sole modality. Their use is more convenient than complex resection techniques in less invasive surgical approaches to treat mitral valve prolapse. Excellent longterm durability of mitral valve repair has been reported using ePTFE chords. ${ }^{5,6}$

Early or late rupture of ePTFE chords is described in the literature but the overall incidence seems to be low. Causes

\footnotetext{
From the Division of Cardiac Surgery, Department of Surgery, Bluhm Cardiovascular Institute, Northwestern University Feinberg School of Medicine and Northwestern Medicine, Chicago, Ill.

Disclosures: Dr McCarthy has received consultant fees and royalties from Edwards Lifesciences, is a member of the Advisory Board for Abbott, and has received an honorarium from Atricure. Dr Pawale has nothing to disclose with regard to commercial support.

Received for publication Nov 12, 2019; revisions received Nov 12, 2019; accepted for publication Nov 17, 2019; available ahead of print Feb 3, 2020.

Address for reprints: Amit Pawale, MD, Northwestern Medicine, $201 \mathrm{E}$ Huron St, Suite 11-140, Chicago, IL 60611-2908 (E-mail: amit.pawale@nm.org).

JTCVS Techniques 2020;1:39-40

2666-2507

Copyright (C) 2020 The Author(s). Published by Elsevier Inc. on behalf of The American Association for Thoracic Surgery. This is an open access article under the CC BY-NC-ND license (http://creativecommons.org/licenses/by-nc-nd/4.0/).

https://doi.org/10.1016/j.xjtc.2019.11.011
}

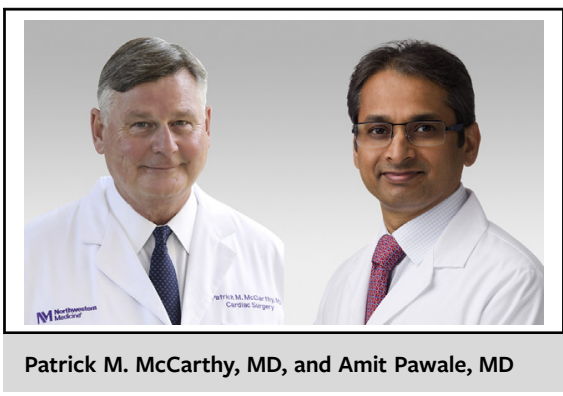

CENTRAL MESSAGE

Late calcific rupture of ePTFE is

rare but reported. Combining

repair techniques and more

neochordae may increase dura-

bility of mitral repair.

of early rupture have been described as mechanical damage from instruments, clips, or friction; and use of CV5 ePTFE instead of CV3. Late rupture due calcific degeneration was first described by Butany and colleagues. ${ }^{7}$ They reported on histologic study that the neochordae were laminated by host fibrosa and endothelium and calcium penetrated the interstices with possible stiffening leading to potential calcification and fracture.

Bortolotti and colleagues $^{8}$ reported a case of possible fatigue-induced late rupture of neochordae, and reviewed 4 cases of late neochordae rupture due to calcific degeneration.

Luthra and colleagues ${ }^{9}$ describe a case of late rupture of neochord due to calcific degeneration, although there is no pathology of the ruptured ePTFE chord.

Given the low but definitive possibility of neochordae rupture, one could consider blending more than one technique to reinforce the repair and/or using more ePTFE chordae for the length of prolapsing segment for a durable mitral valve repair. ${ }^{9,10}$ With different neochordae implantation techniques and use or lack of concurrent mitral valve repair techniques, long-term results of multiple surgeons/groups need to be studied to better understand the long-term durability of neochordae. If limited or no resection of the leaflet has been performed along with use of ePTFE chords at primary repair, re-repair more likely will be possible for recurrent mitral regurgitation due to rupture of neochordae because there could be more preserved leaflet tissue to work with. 


\section{References}

1. Carpentier A. Cardiac valve surgery-the "French correction". J Thorac Cardiovasc Surg. 1983;86:323-37.

2. Vetter HO, Burack JH, Factor SM, Malacuso F, Frater WM. Replacement of chordae tendineae of the mitral valve using the new expanded PTFE suture in sheep. In: Bodnar E, Yacoub M, eds. Biologic and Bioprosthetic Valves. New York: Yorke Medical Books; 1986:772-85.

3. David TE. Replacement of chordae tendineae with expanded polytetrafluoroethylene sutures. J Card Surg. 1989;4:286-90.

4. Zussa C, Frater RW, Polesel E, Galloni M, Valfre C. Artificial mitral valve chordae: experimental and clinical experience. Ann Thorac Surg. 1990;50:367-73.

5. David TE, David CM, Lafreniere-Roula M, Manlhiot C. Long-term outcomes of chordal replacement with expanded polytetrafluoroethylene sutures to repair mitral leaflet prolapse. J Thorac Cardiovasc Surg Tech. August 30, 2019 [Epub ahead of print].
6. Hata H, Fujita T, Shimahara Y, Sato S, Ishibashi-Ueda H, Kobayashi J. A 25-year study of chordal replacement with expanded polytetrafluoroethylene in mitral valve repair. Interact Cardiovasc Thorac Surg. 2015;20: 463-8.

7. Butany J, Collins MJ, David TE. Ruptured synthetic expanded polytetrafluoroethylene chordae tendinae. Cardiovasc Pathol. 2004;13:182-4.

8. Bortolotti U, Celiento M, Pratali S, Anastasio G, Pucci A. Recurrent mitral regurgitation due to ruptured artificial chordae: case report and review of the literature. J Heart Valve Dis. 2012;21:440-3.

9. Luthra S, Ismail A, Tsang G. Calcific degeneration and late fracture expanded polytetrafluoroethylene neochords after mitral valve repair. J Thorac Cardiovasc Surg Tech. 2020;1:34-6.

10. De Paulis R. Commentary: if your pants are too loose, use both belt and suspenders. J Thorac Cardiovasc Surg Tech. September 21, 2019 [Epub ahead of print]. 